\title{
EFFECTS OF THE HERBICIDE PENDIMETHALIN ON HORMONE RECEPTOR EXPRESSIONS AND DORSAL FIN BIOMETRICS IN THAI MEDAKA, ORYZIAS MINUTILLUS (ACTINOPTERYGII: BELONIFORMES: ADRIANICHTHYIDAE)
}

\author{
Arin NGAMNIYOM ${ }^{1}$ and Busaba PANYARACHUN ${ }^{2 *}$ \\ ${ }^{1}$ Srinakharinwirot University, Faculty of Environmental Culture and Eco-tourism, 10110, Bangkok, Thailand \\ ${ }^{2}$ Srinakharinwirot University, Department of Anatomy Faculty of Medicine, 10110, Bangkok, Thailand
}

Ngamniyom A., Panyarachun B. 2012. Effects of the herbicide pendimethalin on hormone receptor expressions and dorsal fin biometrics in Thai medaka, Oryzias minutillus (Actinopterygii: Beloniformes: Adrianichthyidae). Acta Ichthyol. Piscat. 42 (3) 239-246.

\begin{abstract}
Background. Xeno-oestrogens have negative effects on the endocrine systems of wildlife including freshwater fish. Pendimethalin is a herbicide found in the environment which exerts some oestrogenic action in vivo. Dwarf medaka (known also as Thai medaka), Oryzias minutillus Smith, 1945, inhabit the natural aquatic environments. Dorsal fin of this species is a secondary sex character controlled by sex hormones and assumes as a sensitive bioindicator for testing of oestrogenic chemicals. In this study, we aimed to examine the pendimethalin effects on hormone receptor expressions and dorsal fin biometrics in adult Thai medaka.

Materials and methods. Pendimethalin effects on the androgen receptor $(A R)$ and estrogen receptor $(E R) \beta$ expressions in dorsal fins were determined by semi-quantitative RT-PCR. The fin biometry was presented as the values $(\%)$ of the dorsal fin length (DFL) divided by the standard length (SL).

Results. In males, $A R$ levels decreased when the fish were exposed to $0.1 \mu \mathrm{g} \cdot \mathrm{mL}^{-1}$ pendimethalin for 60 days and were exposed to $1 \mu \mathrm{g} \cdot \mathrm{mL}^{-1}$ for 30 and 60 days. In females, a 60 -day treatment with $1 \mu \mathrm{g} \cdot \mathrm{mL}^{-1}$ caused $A R$ levels to decrease. Conversely, in males, $E R \beta$ levels increased after 30 and 60 days of treatment with $1 \mu \mathrm{g} \cdot \mathrm{mL}^{-1}$. In females, $E R \beta$ levels increased after 30 days of treatment with $1 \mu \mathrm{g} \cdot \mathrm{mL}^{-1}$ and 60 days of treatment with $0.1 \mu \mathrm{g} \cdot \mathrm{mL}^{-1}$. In males, values of DFL/SL\% decreased after exposure to $1 \mu \mathrm{g} \cdot \mathrm{mL}^{-1}$ for 60 days. Additionally, we observed 4 testis-ova among 30 gonads from males treated with $1 \mu \mathrm{g} \cdot \mathrm{mL}^{-1}$ for 60 days.

Conclusion. Our results suggest that pendimethalin may interfere with endocrine processes via hormone receptors, leading to the feminisation of dorsal fins and gonads in Thai medaka.
\end{abstract}

Keywords: pendimethalin, androgen receptor, oestrogen receptor $\beta$, Thai medaka

\section{INTRODUCTION}

Environmental xeno-oestrogens are chemicals that interfere with the endocrine systems and cause abnormal physiological processes of reproduction in wildlife (Prado et al. 2011, Fusani et al. 2007). These chemicals can exert hormone activity as an estrogen agonist or antagonist (Choi et al. 2004). The effects of xeno-oestrogens have been described in many teleost fish by measuring the levels of sex hormone gene transcripts, which are transcribed through their hormone receptors in a ligand-dependent manner (Ankley et al. 2009, 2010).

The pendimethalin is an herbicide that is widely used in agricultural fields to control annual grasses and certain broadleaf weeds (Bandyopadhyay and Choudhury 2009). This herbicide has been considered to be a moderately persistent, bioaccumulative toxic compound (Roca et al. 2008), and it has a half-life of approximately 32 days in soil and is broken down by microbial or photocatalytic degradation (Lakshmipathi et al. 2008, Alister et al. 2009, Pinto et al. 2012). After widespread use, pendimethalin was detected as a contaminant in ground water with 0.1 to $6 \mu \mathrm{g} \cdot \mathrm{L}^{-1}$ and in agricultural soil at approximately $13 \mathrm{mg} \cdot \mathrm{kg}^{-1}$ (Barbash and Resek 1996, Strandberg and Scott-Fordsmand 2004).

With regard to fish species, Kidd and James (1991) reported that pendimethalin was toxic to rainbow trout, Oncorhynchus mykiss (Walbaum, 1792), and channel catfish, Ictalurus punctatus (Rafinesque, 1818), with $\mathrm{LC}_{50}$ values of $0.14 \mathrm{mg} \cdot \mathrm{L}^{-1}$ and $0.42 \mathrm{mg} \cdot \mathrm{L}^{-1}$, respectively. Danion et al. (2012) demonstrated that a decrease in phagocytosis activity was found in rainbow trout after the exposure to pendimethalin at $0.8 \mu \mathrm{g} \cdot \mathrm{L}^{-1}$. Moreover, in mammal, Kojima et al. (2004) reported that this herbicide also plays an estrogenic action by inducing the expressions of oestrogen receptor in Chinese hamster ovarian cells.

\footnotetext{
* Correspondence: Dr. Busaba Panyarachun, Srinakharinwirot University, Department of Anatomy Faculty of Medicine, 10110, Bangkok, Thailand, phone: +668-1257-4530, fax: +662-260-1532, e-mail: arin@swu.ac.th,ngamniyom.a@gmail.com.
} 
In teleosts, androgens play crucial roles in the physiological processes regulating sexual differentiation and reproductive development and the spermatogenesis of males by mediating androgen receptors (ARs) (Harbott et al. 2007). ARs belong to a large family of nuclear hormone receptors that are ligand-dependent transcription factors with highly conserved DNA-binding domains and moderately conserved ligand-binding domains (Borg 1994, Todo et al. 1999).

Similar to the function of androgens in males, oestrogens are an important role in physiological functions, including the regulation of sexual development, oogenesis and vitellogenesis, and the maintenance of the female reproductive organs by acting on its target cells via oestrogen receptors (ERs) (Socorro et al. 2000). The ERs are nuclear receptors that are members of the steroid/thyroid hormone receptor superfamily of ligand-inducible transcription factors (Choi 2007). Three $E R$ isoforms ( $E R \alpha$, $E R \beta$ and $E R \gamma$ ) have been described in fish (Chang et al. 1999, Sabo-Attwood et al. 2004). In teleosts, $E R \beta$ is abundantly expressed in several tissues, including the gonads, brain, liver, cartilage, and bone (Socorro et al. 2000, Menuet et al. 2002, Hawkins and Thomas 2004), suggesting that $E R \beta$ is the main $E R$ receptor in teleosts.

Dwarf medaka (known also as Thai medaka), Oryzias minutillus Smith, 1945, is the smallest species in the genus Oryzias, which is widely distributed in Thailand (Magtoon et al. 1992). The habitats of this species are shallow ponds, ditches, and paddy fields; and Thai meda$\mathrm{ka}$ is susceptible to the endocrine-disruptors in its environment (Ngamniyom and Panyarachun 2011). The sex of individual medaka can be determined by analysing the secondary sex characteristics of the dorsal fin: the dorsal fins of males are usually longer than those of females (Ngamniyom et al. 2009), ranging from approximately $3 \mathrm{~mm}$ to $3.5 \mathrm{~mm}$ in males and from $2 \mathrm{~mm}$ to $2.6 \mathrm{~mm}$ in females, under natural condition (Ngamniyom and Panyarachun 2012). Furthermore, the anal fins also exhibited a sexual dimorphism in the size, with the anterior parts of the anal fins being longer in males than in females (Ngamniyom et al. 2009).

The aim of this study was to examine the in vivo effects of pendimethalin on gene expressions by monitoring the levels of androgen receptor $(A R)$ and oestrogen receptor $(E R \beta)$ in the dorsal fins of adult Thai medaka. The biometrics of the dorsal fins was investigated, and the gonads were histologically observed. Therefore, we believed that the presently reported study might contribute to increasing the knowledge of endocrine disruption in teleost. Additionally, we hope our work will serve to advance the understanding of the molecular and physiological mechanisms of xeno-oestrogenic effects on the $A R$ and $E R \beta$ in the dorsal fins of Thai medaka.

\section{MATERIALS AND METHODS}

Fish. Adult Thai medaka with standard length of 14-16 mm were collected from breeding tanks at the Laboratory of the Department of Anatomy, Faculty of
Medicine, Srinakharinwirot University. Sex was determined from the morphology of fins. Males and females were kept in separate aquaria with a $14: 10 \mathrm{~h} \mathrm{light/dark}$ cycle, $\mathrm{pH}(7.0-7.4)$, dissolved oxygen $\left(8.0-8.3 \mathrm{mg} \cdot \mathrm{L}^{-1}\right)$ at $26 \pm 1{ }^{\circ} \mathrm{C}$ for 1 week and fed ad libitum with TetraKilliMin 2 times per day (Tetra, Tokyo, Japan).

Chemical preparation. For the herbicide solutions, $0.1,1$, and $10 \mathrm{mg}$ of pendimethalin (3, 4-dimethyl-2, 6-dinitro-N-pentan-3-yl-aniline) (Wako, Osaka) were dissolved in $1 \mathrm{~mL}$ of dimethyl sulfoxide (DMSO) (Sigma, St. Louis, MO) to make the stock solutions $\left(0.1,1\right.$, and $10 \mathrm{mg} \cdot \mathrm{mL}^{-1}$, respectively). To make solutions at the final concentrations, $0.1 \mathrm{~mL}$ from each stock solution was diluted with $1000 \mathrm{~mL}$ of aquarium water to make concentrations of $0.01,0.1$, and $1 \mu \mathrm{g} \cdot \mathrm{mL}^{-1}$, respectively. In time-group experiments, males or females were immersed in aquarium water containing $1 \mu \mathrm{g} \cdot \mathrm{mL}^{-1}$ pendimethalin solutions for 21,30 , and 60 days (d). In concentration-group experiments, fish were treated with $0.01,0.1$, and $1 \mu \mathrm{g} \cdot \mathrm{mL}^{-1}$ solutions for $60 \mathrm{~d}$. As a control, fish were treated with DMSO in aquarium water without pendimethalin for $60 \mathrm{~d}$.

Time-group experiments were set to investigate the chemical effects of different time treatments with a fixed concentration. However, concentration-group experiments were objected to examine those of various concentrations with a uniform time. Males and females were contained in separate aquaria for time and concentration groups of each experiment under the same conditions as noted above. Therefore, a total of exposure aquaria were twenty, and each treatment was consisted of two aquaria.

For each experiment, $3 \mathrm{~L}$ of the pendimethalin solution in the test aquaria were refreshed with the same concentration of this solution every 3 days. For the treatment of the chemical used in this study, the water was stored in the gallons and then transferred to a wastewater treatment plant. During the exposure periods, fish were fed TetraKilliMin 2 times a day. Our experiments were conducted from August 2010 through the end of November 2011.

According to the percentage of mortality, which is shown in Table 1, the concentrations of herbicide used here are non-lethal and are not acutely toxic for Thai medaka.

Semi-quantitative RT-PCR. Adult fish were anesthetised with $100 \mathrm{mg} \cdot \mathrm{L}^{-1}$ of an ethyl-3-aminobenzoate methanesulphonate (MS-222) solution (Sigma, St. Louis, MO) and placed in a Petri dish. The whole dorsal fins were dissected from 50 males or 50 females of each experiment group. Amount of RNA extraction from five fin tissues was sufficient for RT-PCR conductions. Therefore, the fin samples were combined by 5 to form 10 composite samples for each gender.

Total RNA from each sample was extracted using the Isogen reagent and treated with DNase1 for $30 \mathrm{~min}$ at $37^{\circ} \mathrm{C}$. Total RNA (100 ng) was reverse-transcribed with AMV reverse transcriptase $\mathrm{XL}$, according to the method of Ngamniyom et al. (2009).

The first strand cDNA solution $(0.5 \mu \mathrm{L})$ was used as a PCR template. Primers for the amplification of $A R$ were 5'-CAGGAGGAGTTCCTGTGCAT-3' and 5'-GGTG- 
GTGGTAAGGTGAAGGA-3' (Ngamniyom and Sasayama 2011). The primers for $E R \beta$ were 5'-CTGTTAGATGCCTCGGACCTT-3' and 5'-GATTGGCTGGTTTCGTG -3' (Inui et al. 2003). As a loading control and reference, $\beta$-actin was amplified using primers used were 5'-AGGGAGAAGATGACC-3' and 5'-CGCAGGACGCCATACCAA-3' (Scholz et al. 2004).

The linear phase of each RT-PCR reaction was determined to allow semi-quantitative comparisons of the cDNAs which were developed according to the previous methods of Ngamniyom et al. (2009). Therefore, PCR conditions for the amplification of cDNA were $95^{\circ} \mathrm{C}$ for $30 \mathrm{~s}$ for denaturation; $62^{\circ} \mathrm{C}(A R), 64^{\circ} \mathrm{C}(E R \beta)$, or $58^{\circ} \mathrm{C}(\beta$-actin) for $1 \mathrm{~min}$ for annealing; and $72^{\circ} \mathrm{C}$ for $1 \mathrm{~min}$ for extension. The total cycle numbers were 34 for $A R, 30$ for $E R \beta$, and 20 for $\beta$-actin. The PCR products were analysed by electrophoresis on a $2 \%$ agarose gel, stained with ethidium bromide, and visualised on a UV transilluminator. The intensities of the amplified bands were quantified using the Scion Image

Software for Windows (Scion, Maryland, USA). In housekeeping gene, no effect of pendimethalin on the levels of $\beta$-actin expressions in dorsal fins was found among exposure courses. Therefore, as a control and reference, the intensity of the $A R$ and $E R \beta$ amplified bands from each sample were divided by the intensity of the corresponding $\beta$-actin amplified band to obtain the relative expression levels.

Biometrics of dorsal fin and gonadal histology. The lengths of the dorsal fins were measured using a digital calliper. The measurements of the dorsal fins were evaluated by dividing the dorsal fin length (DFL) by the standard length (SL) and multiplied by 100 . The resulting value was defined as DFL/SL\% (Fig. 1).

Fish gonads were removed from the bodies, fixed in Bouin's solution for $12 \mathrm{~h}$, and stored in $70 \%$ ethanol. The specimens were dehydrated in an ethanol series, embedded in paraffin, and sectioned at $6 \mu \mathrm{m}$ using a manual rotary microtome. The sections were stained with haematoxylin and eosin.

Table 1

Effects of various exposure times and concentrations of pendimethalin on survival and dorsal fin length-standard (fish) length (DFH/SL\%) of adult Thai medaka, Oryzias minutillus

\begin{tabular}{|c|c|c|c|c|c|c|}
\hline & \multirow{2}{*}{$\begin{array}{c}\text { Exposure } \\
\text { time } \\
\text { [day] }\end{array}$} & \multirow{2}{*}{$\begin{array}{l}\text { Pendimethalin } \\
\text { concentration } \\
{\left[\mu \mathrm{g} \cdot \mathrm{mL}^{-1}\right]}\end{array}$} & \multicolumn{2}{|c|}{$\begin{array}{c}\text { Number of survived } \\
\text { individuals [\%] }\end{array}$} & \multicolumn{2}{|c|}{ DFL/SL\% } \\
\hline & & & Male & Female & Male & Female \\
\hline Control group & 60 & - & 100 & 94.5 & $20.9 \pm 0.04^{\mathrm{a}}$ & $17.0 \pm 0.07$ \\
\hline \multirow{5}{*}{$\begin{array}{l}\text { Treatment } \\
\text { groups }\end{array}$} & 14 & 1 & 98.2 & 94.5 & $20.3 \pm 0.06^{\mathrm{ab}}$ & $16.8 \pm 0.04$ \\
\hline & 30 & 1 & 94.5 & 96.4 & $19.8 \pm 0.05^{\mathrm{ab}}$ & $17.1 \pm 0.06$ \\
\hline & 60 & 1 & 96.4 & 96.4 & $19.1 \pm 0.06^{\mathrm{b}}$ & $16.7 \pm 0.04$ \\
\hline & 60 & 0.01 & 94.5 & 100 & $20.7 \pm 0.06^{\mathrm{a}}$ & $17.2 \pm 0.04$ \\
\hline & 60 & 0.1 & 92.7 & 90.9 & $20.4 \pm 0.04^{\mathrm{a}}$ & $16.9 \pm 0.03$ \\
\hline
\end{tabular}

Note: Each experiment involved 55 adult males or 55 females; The values of DFL/SL\% (mean \pm SE) were compared between experiments of male or female groups; Significant differences of values indicated by dissimilar alphabets (One-way ANOVA with Tukey's multiple comparison test; $P<0.05$ ).

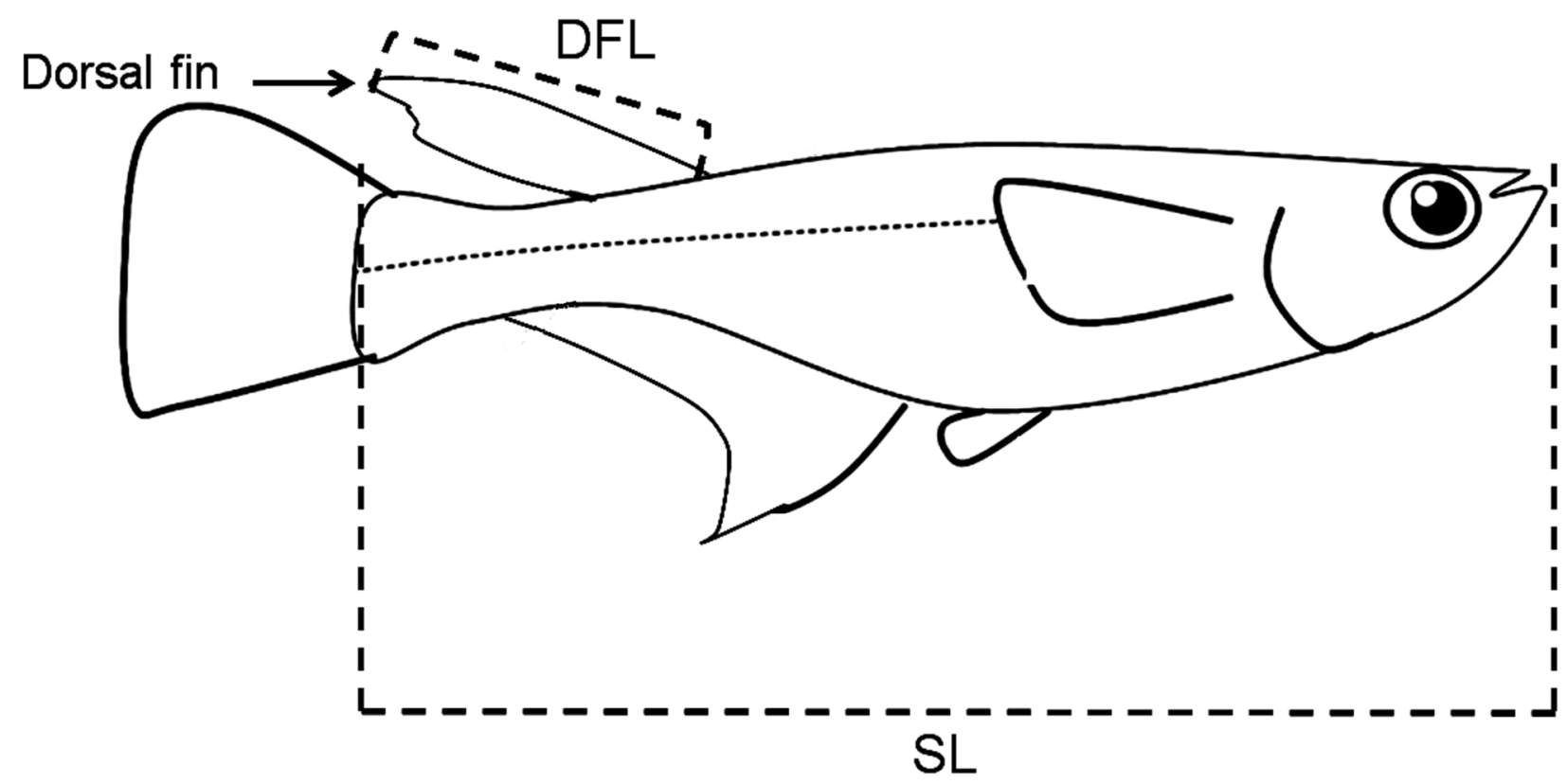

Fig. 1. Diagrammatic illustration of measurement of standard length (SL) of Thai medaka, Oryzias minutillus, and the length of its dorsal fin (DFL); $\mathrm{CC}=$ caudal peduncle 
Statistic analysis. One-way ANOVA with Tukey's multiple comparison test was used to examine the statistical significance of differences. The data were analysed with Statistical Package for the Social Sciences (SPSS) for Windows, version 14 (SPSS, Chicago, USA).

This experimental design was approved by the ethics committee of the Srinakharinwirot University, Department of Anatomy Faculty of Medicine, Thailand in accordance with the recommendations of the Guidelines for the Care and Use of Fish in Research, Teaching and Testing (http://ccac.ca/Documents/Standards/Guidelines/Fish.pdf).

\section{RESULTS}

Effect of pendimethalin on the level of AR mRNA expression in dorsal fins. In males, the $A R$ expression levels in dorsal fin significantly decreased after treatments with $1 \mu \mathrm{g} \cdot \mathrm{mL}^{-1}$ pendimethalin for 30 and $60 \mathrm{~d}$ and after treatment with $0.1 \mu \mathrm{g} \cdot \mathrm{mL}^{-1}$ for $60 \mathrm{~d}$ (Figs. 2A-B). In females, the $A R$ levels in the dorsal fin significantly decreased after treatment with $1 \mu \mathrm{g} \cdot \mathrm{mL}^{-1}$ pendimethalin for $60 \mathrm{~d}$ (Figs. 2C-D).

Effect of pendimethalin on the level of ER $\beta$ mRNA expression in dorsal fins. In males, the $E R \beta$ expression levels in dorsal fin significantly increased after treatments with $1 \mu \mathrm{g} \cdot \mathrm{mL}^{-1}$ pendimethalin for 30 and $60 \mathrm{~d}$ (Figs. $3 \mathrm{~A}-\mathrm{B})$. In females, the $E R \beta$ levels in dorsal fin significantly increased after treatments of $1 \mu \mathrm{g} \cdot \mathrm{mL}^{-1}$ pendimethalin for $14 \mathrm{~d}$ (Figs. 3C-D) and treatments with $0.1 \mu \mathrm{g} \cdot \mathrm{mL}^{-1}$ pendimethalin for $60 \mathrm{~d}$ (Figs. 3C-D).

Effect of pendimethalin on biometrics of dorsal fins and gonadal histology. In males, the values of DFL/SL\% in dorsal fin significantly decreased in the treatment with $1 \mu \mathrm{g} \cdot \mathrm{mL}^{-1}$ pendimethalin for $60 \mathrm{~d}$ from control, $0.01,0.1$
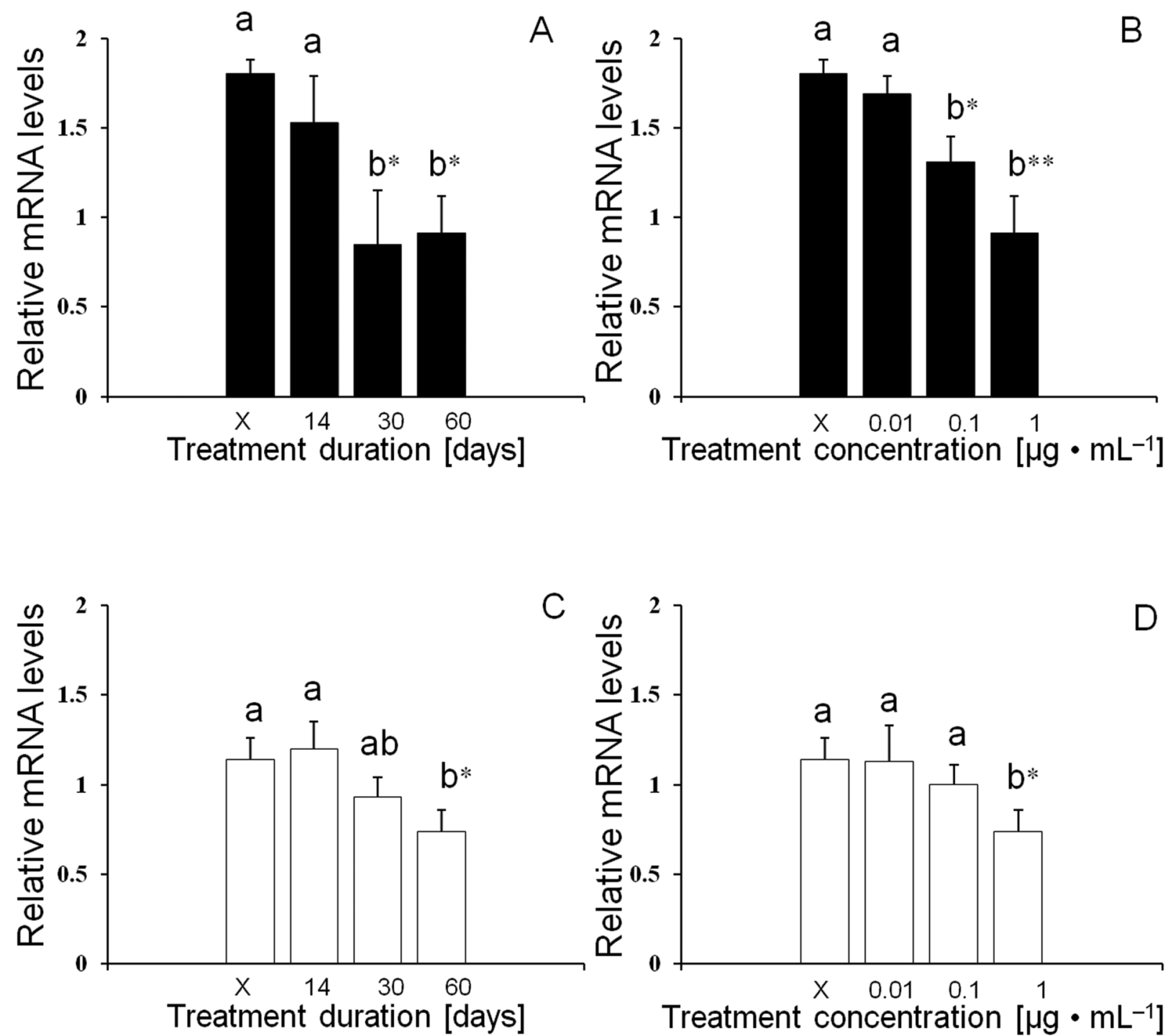

Fig. 2. Time- $(\mathbf{A}, \mathbf{C})$ and concentration-dependent $(\mathbf{B}, \mathbf{D})$ effects of pendimethalin on androgen receptor $(A R) \mathrm{mRNA}$ expression level in the dorsal fins of male $(\mathbf{A}, \mathbf{B})$ and female $(\mathbf{C}, \mathbf{D})$ Thai medaka, Oryzias minutillus, as examined by a semi-quantitative RT-PCR; X = control groups (were treated with dimethyl sulfoxide); The expression levels in each sample are relative values compared to those of $\beta$-actin mRNA (mean $+\mathrm{SE}$ ). Dissimilar letters indicate significant differences (one-way ANOVA with Tukey's multiple comparison test; $*=P<0.05$ and $* *=P<0.01$, respectively) 
treatment groups for $60 \mathrm{~d}$. In females, no significant change in the values of DFL/SL $\%$ of dorsal fin was found after pendimethalin treatments (Table 1) (Figs. 4A-C).

The testes from all male gonads were histologically observed after the treatments with 0.01 and $0.1 \mu \mathrm{g} \cdot \mathrm{mL}^{-1}$ pendimethalin for $60 \mathrm{~d}$ and treatments with $1 \mu \mathrm{g} \cdot \mathrm{mL}^{-1}$ for 14 and $30 \mathrm{~d}$. In contrast, 4 testis-ova were identified among the 30 gonads of males treated with $1 \mu \mathrm{g} \cdot \mathrm{mL}^{-1}$ pendimethalin for $60 \mathrm{~d}$. In females, the ovaries from all gonads in the time-and concentration -group experiments were observed (Figs. 5A-C).

\section{DISCUSSION}

In this study, we examined the effects of herbicide pendimethalin on the expression levels of the $A R$ and $E R \beta$ mRNAs in the dorsal fins of Thai medaka. We found that this agricultural chemical might have an estrogenic activity in fish.

In Thai medaka, $A R$ expression levels in the dorsal fins of males and females were down-regulated by exposure of pendimethalin. The dorsal fins of male fish also decreased in the length after exposure to this chemical. It is well known that the administration of an estrogen is an ability to transform the male to female phenotypes in the dorsal and anal fin of Japanese medaka (Iwamatsu 1999, Foran et al 2000). Therefore, pendimethalin may suppress the growth of the male dorsal fin by inhibiting $A R$ expression levels and, thus, correspond with the previous reports of Ngamniyom et al. (2012), which showed that $A R$ transcript levels decreased and male anal fins were shortened in Thai medaka that were exposed to xeno-oestrogenic mestranol. On the contrary, the lengths of the female dorsal fin did not change, although the $A R$ levels were down-
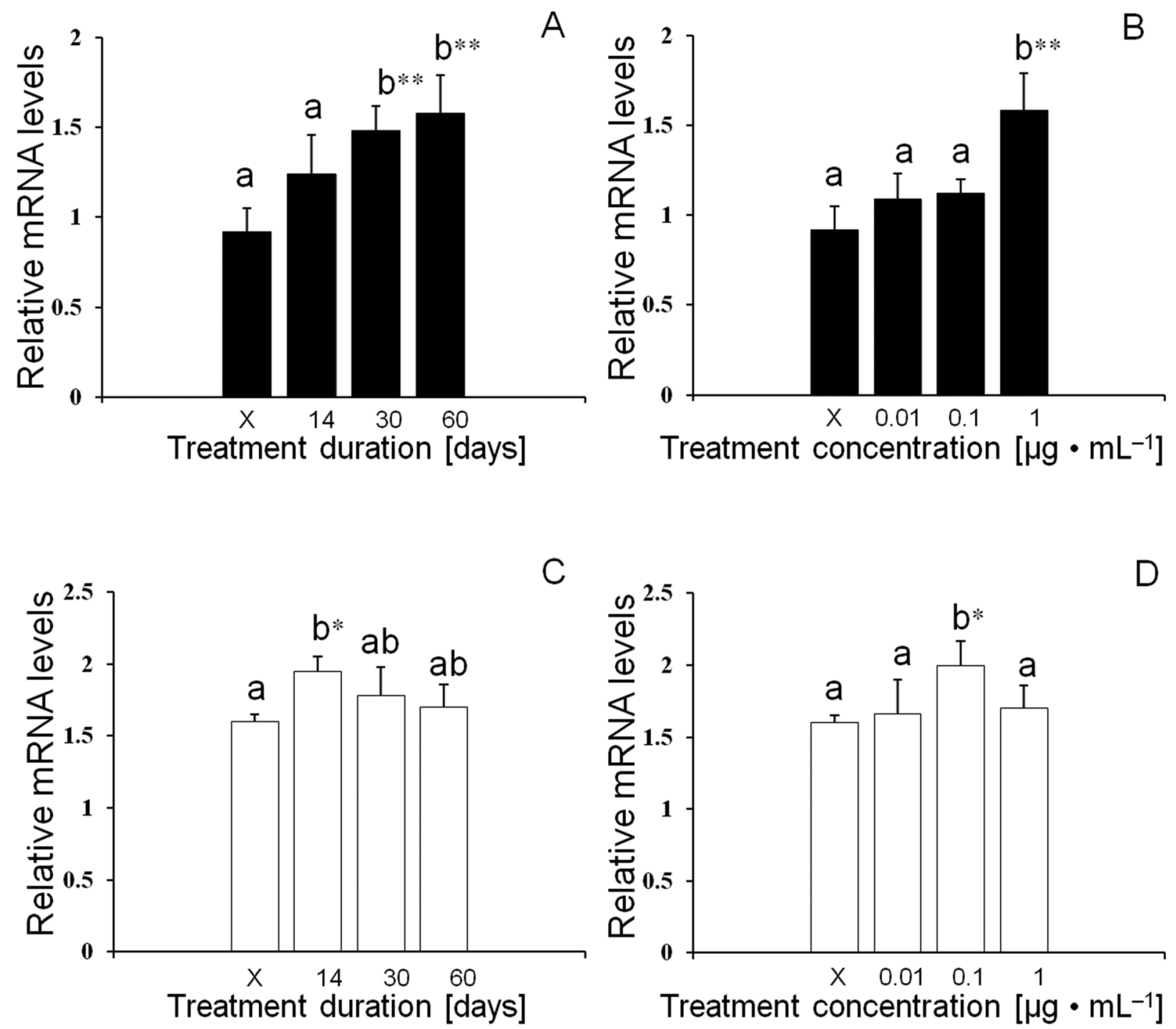

Fig. 3. Time- $(\mathbf{A}, \mathbf{C})$ and concentration-dependent $(\mathbf{B}, \mathbf{D})$ effects of pendimethalin on estrogen receptor $(E R) \beta$ mRNA expression level in dorsal fins of male $(\mathbf{A}, \mathbf{B})$ and female $(\mathbf{C}, \mathbf{D})$ Thai medaka, Oryzias minutillus, as examined by a semi-quantitative RT-PCR; $\mathrm{X}=$ control groups (were treated with dimethyl sulfoxide); The expression levels in each sample are relative values compared to those of $\beta$-actin mRNA (mean $+\mathrm{SE}$ ); Dissimilar letters indicate significant differences (one-way ANOVA with Tukey's multiple comparison test; $*=P<0.05$ and $* *=P<0.01$, respectively) 


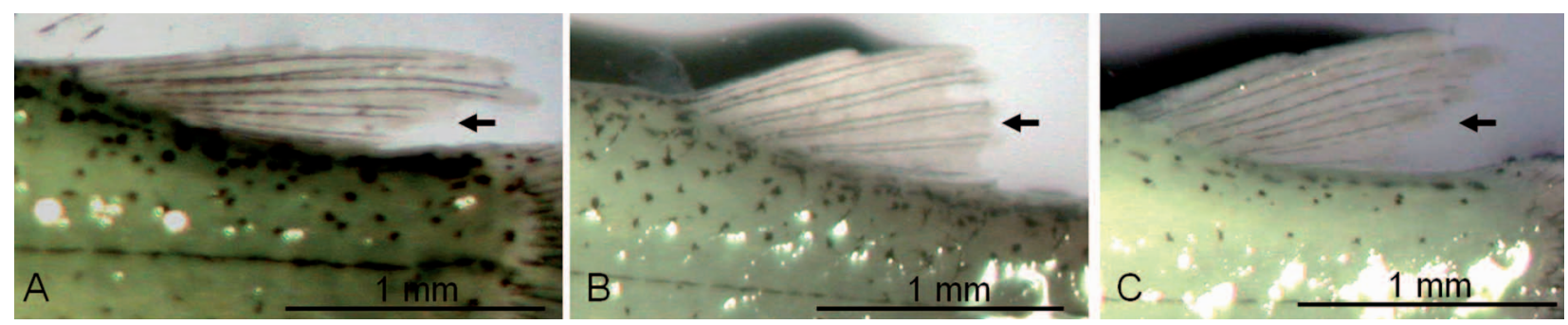

Fig. 4. Characteristics of the dorsal fin of untreated (A) male and (B) female of Thai medaka, Oryzias minutillus; (C) Dorsal fin of male exposed to $1 \mu \mathrm{g} \cdot \mathrm{mL}^{-1}$ pendimethalin for 60 days
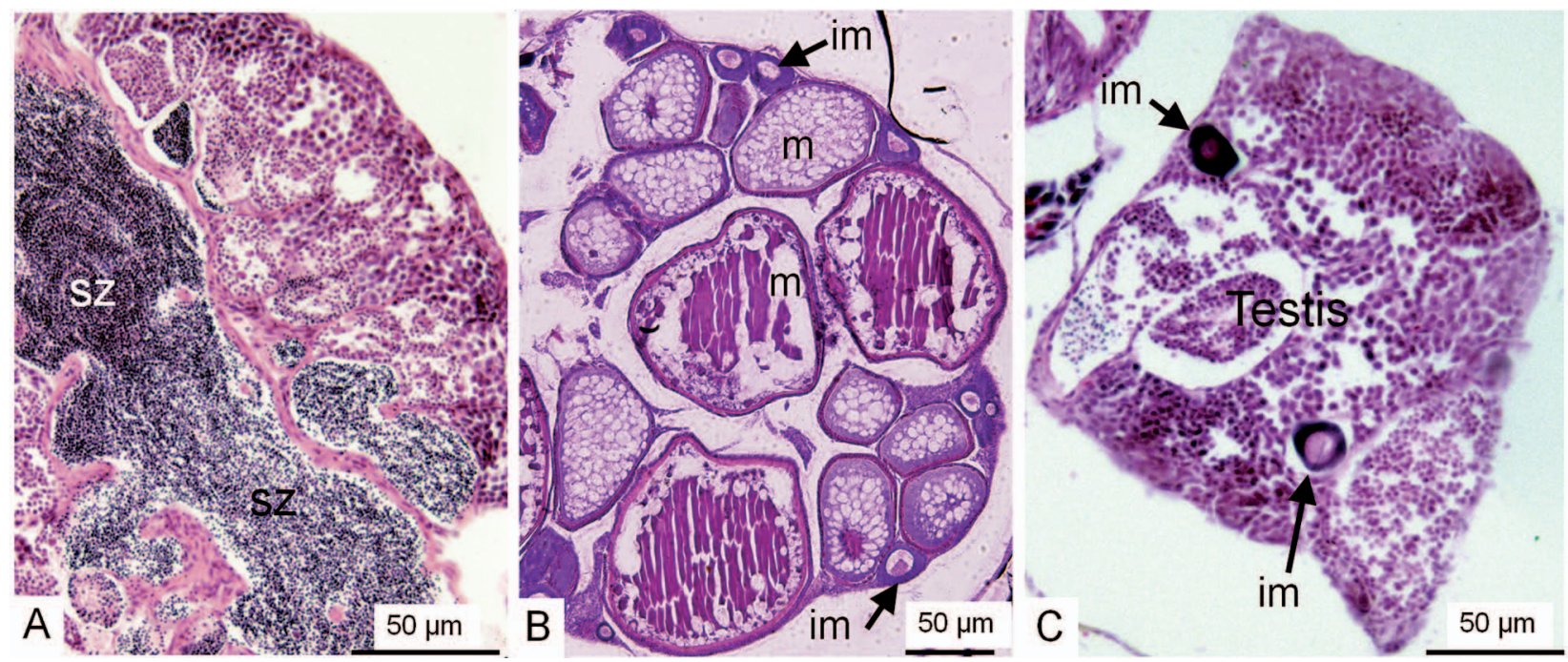

Fig. 5. Histological analysis of gonads from untreated (A) male and (B) female of Thai medaka, Oryzias minutillus; (C) Oocyte development in the testicular tissue of a male exposed to $1 \mu \mathrm{g} \cdot \mathrm{mL}^{-1}$ pendimethalin for 60 days; $\mathrm{sz}=$ spermatozoa, $\mathrm{m}=$ mature oocyte, $\mathrm{im}=$ immature oocyte

regulated after pendimethalin treatments. Pendimethalin may exert an estrogenic effect toward $E R \beta$ for maintaining the female phenotype in dorsal fins.

In teleost, the induction of $E R$ expression by exposure of various xeno-oestrogens has been examined in the liver, brain, gonad and fin tissues; the tested xeno-oestrogens include propyl-pyrazole-triol (PPT) (Leaños-Castañeda and Van Der Kraak 2007), 4-nonylphenol (Meucci and Arukwe 2006), 17 $\alpha$-ethinylestradiol (Islinger et al. 2003) and bisphenol A (Hayashi et al. 2007). In Thai medaka, increases in $E R \beta$ expression levels were observed in the dorsal fin tissues of both sexes after treatments with pendimethalin. This result is consistent with the report by Kojima et al. (2004) showing that pendimethalin exhibited an estrogenic activity to stimulate the $E R \alpha$ mRNA expression levels in Chinese hamster ovary cells. The reason for decreasing the lengths of dorsal fins in males by pendimethalin treatments was discussed above.

In histological analysis of adult gonads, oocyte-like cells were found in the male testes of Thai medaka treated with pendimethalin. Similarly, Gray et al. (1999) reported that in Japanese medaka, the number of testisova in adult fish was lower than that in fry after exposure to octylphenol, suggesting that the stages of gonadal differentiation were optimal for the incidence of testis-ova by the exposure to estrogenic chemicals. On the other hand, Papoulias et al. (2003) showed that ovo exposure to xeno-oestrogenic DDE did not affect the evidence of intersex gonads in Japanese medaka, Oryzias latipes (Temminck et Schlegel, 1846), although DDE can interact with hepatic estrogen binding sites and induce vitellogenesis in rainbow trout (Donohoe and Curtis 1996). Taking these results into the conclusion, pendimethalin affects the development of adult gonads in fish by acting as agonistic of estrogen, causing an intersex condition in some male gonads.

To the best of our knowledge, the present study is the first to demonstrate that herbicide pendimethalin may affect the development of dorsal fins and gonads by $A R$ and $E R \beta$-mediated antiandrogenic and estrogenic activity, respectively and lead to some feminisation in adult males of Thai medaka. Furthermore, the secondary sex character of dorsal fins may serve as a potential bioindicator for testing the effect of endocrine-disrupting chemicals.

\section{REFERENCES}

Alister C.A., Gomez P.A., Rojas S., Kogan M. 2009. Pendimethalin and oxyfluorfen degradation under two irrigation conditions over four years application. Journal of Environmental Science and Health, Part B: Pesticides, Food Contaminants, and Agricultural Wastes 44 (4): 337-343. DOI: $10.1080 / 03601230902800986$ 
Ankley G.T., Bencic D.C., Breen M.S., Collette T.W., Conolly R.B., Denslow N.D., Edwards S.W., Ekman D.R., GarciaReyero N., Jensen K.M., Lazorchak J.M., Martinović D., Miller D.H., Perkins E.J., Orlando E.F., Villeneuve D.L., Wang R.-L., Watanabe K.H. 2009. Endocrine disrupting chemicals in fish: Developing exposure indicators and predictive models of effects based on mechanism of action. Aquatic Toxicology 92 (3): 168-178.

DOI: $10.1016 /$ j.aquatox.2009.01.013

Ankley G.T., Jensen K.M., Kahl M.D., Durhan E.J., Makynen E.A., Cavallin J.E., Martinović D., Wehmas L.C., Mueller N.D., Villeneuve D.L. 2010. Use of chemical mixtures to differentiate mechanisms of endocrine action in a small fish model. Aquatic Toxicology 99 (3): 389-396. DOI: $10.1016 /$ j.aquatox.2010.05.020

Bandyopadhyay S., Choudhury P.P. 2009. Leaching behaviour of pendimethalin causes toxicity towards different cultivars of Brassica juncea and Brassica campestris in sandy loam soil. Interdisciplinary Toxicology 2 (4): 250-253. DOI: $10.2478 / \mathrm{v} 10102-009-0025-\mathrm{z}$

Barbash J.E., and Resek, E.A. 1996. Pesticides in ground water: Distribution, trends, and governing factors. Pp. 588-590. In: Gilliom R.J. (ed.) Pesticides in the hydrologic system. Ann Arbor Press, Chelsea, Michigan, USA.

Borg B. 1994. Androgens in teleost fishes. Comparative Biochemistry and Physiology, Part C: Pharmacology, Toxicology and Endocrinology 9 (3): 219-245. DOI: $10.1016 / 0742-8413(94) 00063-\mathrm{G}$

Chang X., Kobayashi T., Todo T., Ikeuchi T., Yoshiura M., Kajiura-Kobayashi H., Morrey C., Nagahama Y. 1999. Molecular cloning of estrogen receptors $\alpha$ and $\beta$ the ovary of a teleost fish, the tilapia (Oreochromis niloticus). Zoological Science 16 (4): 653-658.

DOI: $10.2108 /$ zsj.16.653

Choi S.M., Yoo S.D., Lee B.M. 2004. Toxicological characteristics of endocrine-disrupting chemicals: Developmental toxicity, carcinogenicity, and mutagenicity. Journal of Toxicology and Environmental Health, Part B: Critical Reviews 7 (1): 1-23. DOI: $10.1080 / 10937400490253229$

Danion M., Le Floch S., Kanan R., Lamour F., Quentel C. 2012. Effects of in vivo chronic exposure to pendimethalin/Prowl $400 \AA$ on sanitary status and the immune system in rainbow trout (Oncorhynchus mykiss). Science of the Total Environment 424: 143-152. DOI: $10.1016 /$ j.scitotenv.2012.02.055

Donohoe R.M., Curtis L.R. 1996. Estrogenic activity of chlordecone, o,p'-DDT and o,p'-DDE in juvenile rainbow trout: Induction of vitellogenesis and interaction with hepatic estrogen binding sites. Aquatic Toxicology 36 (1-2): 31-52. DOI: 10.1016/S0166-445X(96)00799-0

Foran C.M., Bennett E.R., Benson W.H. 2000. Developmental evaluation of a potential non-steroidal estrogen: triclosan. Marine Environmental Research 50 (1-5): 153-156. DOI: $10.1016 / \mathrm{S} 0141-1136(00) 00080-5$

Fusani L., Della Seta D., Dessì-Fulgheri F., Farabollini F. 2007. Altered reproductive success in rat pairs after environmental-like exposure to xenoestrogen. Proceedings of the
Royal Society, Part B: Biological Sciences 274 (1618): 1631-1636.

DOI: $10.1098 / \mathrm{rspb} .2007 .0064$

Gray M.A., Niimi A.J., Metcalfe C.D. 1990. Factors affecting the development of testis-ova in medaka, Oryzias latipes, exposed to octylphenol. Environmental Toxicology and Chemistry 18 (8): 1835-1842.

DOI: $10.1002 /$ etc. 5620180834

Harbott L.K., Burmeister S.S., White R.B., Vagell M., Fernald R.D. 2007. Androgen receptors in a cichlid fish, Astatotilapia burtoni: Structure, localization, and expression levels. Journal of Comparative Neurology and Psychology 504 (1): $57-73$.

DOI: $10.1002 /$ cne. 21435

Hawkins M.B., Thomas P. 2004. The unusual binding properties of the third distinct teleost estrogen receptor subtype $E R \beta a$ are accompanied by highly conserved amino acid changes in the ligand binding domain. Endocrinology 145 (6): 2968-2977. DOI: $10.1210 /$ en.2003-0806

Hayashi H., Nishimoto A., Oshima N., Iwamuro S. 2007. Expression of the estrogen receptor alpha gene in the anal fin of Japanese medaka, Oryzias latipes, by environmental concentrations of bisphenol A. Journal of Toxicological Sciences 32 (1): 91-96. DOI: $10.2131 /$ jts.32.91

Inui M., Adachi T., Takenaka S., Inui H., Nakazawa M., Ueda M., Watanabe H., Mori C., Iguchi T., Miyatake K. 2003. Effect of UV screens and preservatives on vitellogenin and choriogenin production in male medaka (Oryzias latipes). Toxicology 194 (1-2): 43-50.

DOI: $10.1016 / \mathrm{S} 0300-483 \mathrm{X}(03) 00340-8$

Islinger M., Willimski D., Völkl A., Braunbeck T. 2003. Effects of 17a-ethinylestradiol on the expression of three estrogenresponsive genes and cellular ultrastructure of liver and testes in male zebrafish. Aquatic Toxicology 62 (2): 85-103. DOI: $10.1016 / \mathrm{S} 0166-445 \mathrm{X}(02) 00049-8$

Iwamatsu T. 1999. Convenient method for sex reversal in a freshwater teleost, the medaka. Journal of Experimental Zoology 283 (2): 210-214.

DOI: $\quad 10.1002 /(S I C I) 1097-010 X(19990201) 283: 2<210:: A I D-$ JEZ12>3.0.CO;2-F

Kidd H., James D.R. (eds.) 1991. The agrochemicals handbook. 3rd edn. The Royal Society of Chemistry, Cambridge, UK.

Kojima H., Katsura E., Takeuchi S., Niiyama K., Kobayashi K. 2004. Screening for estrogen and androgen receptor activities in 200 pesticides by in vitro reporter gene assays using Chinese hamster ovary cells. Environmental Health Perspectives 112 (5): 524-531.

PMCID: PMC1241915

Lakshmipathi N., Gomathi D., Krishnamurthy G. 2008. Photocatalytic degradation of the herbicide pendimethalin using nanoparticles of $\mathrm{BaTiO}_{3} / \mathrm{TiO}_{2}$ prepared by gel to crystalline conversion method: A kinetic approach. Journal of Environmental Science and Health, Part B: Pesticides, Food Contaminants, and Agricultural Wastes 43 (7): 553-561. DOI: $10.1080 / 03601230802234351$

Leaños-Castañeda O., Van Der Kraak G. 2007. Functional characterization of estrogen receptor subtypes, ER $\alpha$ and 
ER $\beta$, mediating vitellogenin production in the liver of rainbow trout. Toxicology and Applied Pharmacology 224 (2): $116-125$.

DOI: 10.1016/j.taap.2007.06.017

Magtoon W., Nadee N., Higsdhitani T., Takaha K., Uwa H. 1992. Karyotype evolution and geographical distribution of the Thai-medaka, Oryzias minutillus, in Thailand. Journal of Fish Biology 41 (3): 483-497. DOI: $10.1111 / j .1095-8649.1992 . t b 02676 . x$

Menuet A., Pellegrini E., Anglade I., Blaise O., Laudet V., Kah O., Pakdel F. 2002. Molecular characterization of three estrogen receptor forms in zebrafish: Binding characteristics, transactivation properties, and tissue distributions. Biology of Reproduction 66 (6): 1881-1892. DOI: 10.1095/biolreprod66.6.1881

Meucci V., Arukwe A. 2006. Transcriptional modulation of brain and hepatic estrogen receptor and P450arom isotypes in juvenile Atlantic salmon (Salmo salar) after waterborne exposure to the xenoestrogen, 4-nonylphenol. Aquatic Toxicology 77 (2): 167-177. DOI: $10.1016 / j$.aquatox.2005.11.008

Ngamniyom A., Magtoon W., Nagahama Y., Sasayama Y. 2009. Expression levels of hormone receptors and bone morphogenic protein in fins of medaka. Zoological Science 26 (1): 74-79. DOI: $10.2108 / \mathrm{zsj} .26 .74$

Ngamniyom A., Panyarachun B. 2011. Expression levels of hormone receptor and vitellogenin mRNAs in livers of Thai medaka, Oryzias minutillus, inhabiting the suburbs of Bangkok, Thailand. Journal of Fisheries and Aquatic Science 6 (4): 438-446. DOI: $10.3923 /$ jfas.2011.438.446

Ngamniyom A., Panyarachun B. 2012. Morphometry and hormone receptor expressions in dorsal and anal fins of Thai medaka, Oryzias minutillus, between breeding and nonbreeding seasons. Journal of Fisheries and Aquatic Science 7 (1): 39-48.

DOI: $10.3923 /$ jfas. 2012.39 .48

Ngamniyom A., Sasayama Y. 2011. Expression levels of sex hormone receptors in brains of Japanese medaka, Oryzias latipes (Actinopterygii: Beloniformes: Adrianichthyidae). Acta Ichtyologica et Piscatoria. 41 (1): 29-35.

DOI: 10.3750/AIP2011.41.1.05

Ngamniyom A., Silprasit K., Panyarachun B. 2012. Effects of pharmaceutical Mestranol on estrogen receptor $\beta$ mRNA expression levels and morphometry in the anal fins of adult Thai ricefish (Oryzias minutillus). Kasetsart Journal: Natural Science 43: 80-90.

Papoulias D.M., Villalobos S.A., Meadows J., Noltie D.B., Giesy J.P., Tillitt D.E. 2003. In ovo exposure to o,p -DDE affects sexual development but not sexual differentiation in Japanese medaka (Oryzias latipes). Environmental Health Perspectives 111 (1): 29-32.

DOI: $10.1289 /$ ehp. 5540

Pinto A.P., Serrano C., Pires T., Mestrinho E., Dias L., Martins Teixeira D., Caldeira A.T. 2012. Degradation of terbuthylazine, difenoconazole and pendimethalin pesticides by selected fungi cultures. Science of the Total Environment 435-436: 402-410.

DOI: $10.1016 /$ j.scitotenv.2012.07.027

Prado P.S., Souza C.C., Bazzoli N., Rizzo E. 2011. Reproductive disruption in lambari Astyanax fasciatus from a southeastern Brazilian reservoir. Ecotoxicology and Environmental Safety 74 (7): 1879-87.

DOI: 10.1016/j.ecoenv.2011.07.017

Roca E., D'Errico E., Izzo A., Strumia S., Esposito A., Fiorentino A. 2009. In vitro saprotrophic basidiomycetes tolerance to pendimethalin. International Biodeterioration and Biodegradation 63 (2): 182-186.

DOI: $10.1016 /$ j.ibiod.2008.08.004

Sabo-Attwood T., Kroll K.J., Denslow N.D. 2004. Differential expression of largemouth bass (Micropterus salmoides) estrogen receptor isotypes alpha, beta, and gamma by estradiol. Molecular and Cellular Endocrinology 218 (1-2): 107-118. DOI: $10.1016 /$ j.mce.2003.12.007

Scholz S., Kordes C., Hamann J., Gutzeit H.O. 2004. Induction of vitellogenin in vivo and in vitro in the model teleost medaka (Oryzias latipes): comparison of gene expression and protein levels. Marine Environmental Research 57 (3): 235-244.

DOI: $10.1016 / \mathrm{S} 0141-1136(03) 00082-5$

Socorro S., Power D.M., Olsson P.E., Canario A.V. 2000. Two estrogen receptors expressed in the teleost fish, Sparus aurata: cDNA cloning, characterization and tissue distribution. Journal of Endocrinology 166 (2): 293-306.

DOI: $10.1677 /$ joe. 0.1660293

Strandberg M., Scott-Fordsmand J.J. 2004. Effects of pendimethalin at lower trophic levels-a review. Ecotoxicology and Environmental Safety 57 (2): 190-201. DOI: $10.1016 /$ j.ecoenv.2003.07.010

Todo T., Ikeuchi T., Kobayashi T., Nagahama Y. 1999. Fish androgen receptor: cDNA cloning, steroid activation of transcription in transfected mammalian cells, and tissue mRNA levels. Biochemical and Biophysical Research Communications 254 (2): 378-383.

DOI: $10.1006 /$ bbrc. 1998.9919

Received: 24 March 2012

Accepted: 10 September 2012

Published electronically: 30 September 2012 